\title{
Peranan FMA Glomus sp. dan Pupuk Anorganik terhadap Produktivitas Tanaman Kedelai (Glycine max (L.) Merrill) var. Lokal Bali
}

\section{The Role of AMF Glomus sp. and Inorganic Fertilizer on Bali Local Soybean (Glycine max (L.) Merrill) Productivity}

\author{
Triarta NA ${ }^{1}$, Proborini MW ${ }^{1}$, Hardini $\mathbf{J}^{1}$ \\ ${ }^{1}$ Program Studi Biologi, Fakultas Matematika dan Ilmu Pengetahuan Alam, Universitas Udayana. Jl. Raya \\ Kampus UNUD, Jimbaran, Kuta Selatan, 80361, Bali, Indonesia.
}

Triarta NA, Proborini MW, Hardini J. 2019 - Peranan FMA Glomus sp. dan Pupuk Anorganik Terhadap Produktivitas Tanaman Kedelai (Glycine max (L.) Merrill) var. Lokal Bali. Jurnal Mikologi Indonesia 3(2), 84-94.

\begin{abstract}
Abstrak
Produktivitas tanaman kedelai (Glycine max var. Lokal Bali) dapat ditingkatkan melalui pemupukan. Salah satu pupuk hayati yang bisa diaplikasi sebagai pendamping pupuk anorganik adalah fungi mikoriza arbuskula (FMA). Penelitian ini bertujuan untuk mengetahui peranan FMA Glomus sp. dan pupuk NK terhadap produktivitas tanaman kedelai lokal Bali. Penelitian ini dilakukan di laboratorium Taksonomi Tumbuhan/Mikologi dan Shading house Program Studi Biologi, Fakultas Matematika dan Ilmu Pengetahuan Alam, Universitas Udayana. Penelitian ini menggunakan Racangan Acak Kelompok (RAK) dengan 5 perlakuan yaitu (A) Tanah steril (kontrol) atau tanpa inokulasi FAM dan pupuk NK; (B) Tanah steril, 50 spora Glomus sp.; (C) Tanah steril, 50 spora Glomus sp. dan pupuk NK 5 g; (D) Tanah steril, 50 spora Glomus sp. dan pupuk NK $10 \mathrm{~g}$; (E) Tanah steril, 50 spora Glomus sp. dan pupuk NK 15 g. Variabel yang diamati adalah tinggi tanaman, berat kering tajuk, berat kering akar, jumlah polong isi dan polong hampa, berat basah dan berat kering polong, dan persentase kolonisasi FMA Glomus sp. Hasil penelitian menunjukkan bahwa pemberian 50 butir spora Glomus sp. dan pupuk NK $5 \mathrm{~g}$ pada perlakuan C berperan meningkatkan produktivitas tanaman kedelai terlihat pada jumlah polong isi sebanyak 51 polong per tanaman yang berbeda nyata secara statistik dan memiliki berat kering sebesar 9,10 g, tetapi tidak memberikan pengaruh yang berbeda nyata terhadap pertumuhan tanaman kedelai.
\end{abstract}

Kata kunci - pertumbuhan - produksi kedelai - pupuk kimia

\begin{abstract}
The productivity of soybean (Glycine max var. Local Bali) can be increased through fertilization. One of the biological fertilizers that can be applied as a companion to inorganic fertilizers is arbuscula mycorhiza fungi $(A M F)$. The aim of this study was to determine the role of AMF Glomus sp. and NK fertilizer for Bali local soybean productivity. The study were conducted in the Laboratory of Plant Taxonomy/Mycology and Shading house of Biology Department, Faculty of Mathematics and Natural Sciences, Udayana University. Five treatments of Randomized Block Design (RBD) were used in the experiment, i.e. (A) Sterilized soil (negative control) without inoculation AMF and NK fertilizer; (B) Sterilized
\end{abstract}

Dikirimkan 30 Oktober 2019, Diterima 30 November 2019, Terbit online 31 Desember 2019

Corresponding Author: Meitini Wahyuni Proborini - e-mail - pmeitini@unud.ac.id 
soil, 50 spores Glomus sp.; (C) Sterilized soil, 50 spores Glomus sp. and 5 g NK fertilizer; (D) Sterilized soil, 50 spores Glomus sp. and $10 \mathrm{~g}$ NK fertilizer; (E) Sterilized soil, 50 spores Glomus sp. and $15 \mathrm{~g} \mathrm{NK}$ fertilizer. The observed variables include the plant height, dry weight of plant canopy, dry weight of plant roots, number of filled pods and empty pods, fresh weight and dry weight of pods, and percentage of AMF Glomus sp. The result showed the application of 50 Glomus sp. spores and $5 \mathrm{~g} \mathrm{NK}$ fertilizer in the treatment of $C$ statistically exhibited significant effect on the productivity of soybean, which was seen on number of pods (51 pods for each plant) and dry weight of pods $(9.10 \mathrm{~g})$, but had no significant effect on the soybean growth.

Key words - chemical fertilizer - growth - soybean production

\section{Pendahuluan}

Komoditas pangan ketiga yang paling diminati di Indonesia setelah padi dan jagung adalah kedelai. Kedelai memiliki peran sebagai sumber protein nabati yang penting dalam rangka peningkatan gizi masyarakat. Kebutuhan kedelai per tahun rata-rata sebanyak 2,2 juta ton dan sebanyak 67,99\% dari kebutuhan tersebut merupakan kedelai impor (Kementerian Pertanian 2016). Hal ini didukung oleh Aimon \& Satrianto (2014), bahwa permintaan masyarakat akan kedelai terus meningkat sehingga ketersediaan di pasar tidak mencukupi. Tingginya permintaan akan kedelai tidak dapat diimbangi dengan produksi kedelai tersebut, sehingga impor kedelai di Indonesia ikut meningkat, menyebabkan pasar Indonesia dikuasai kedelai impor yang artinya petani akan bersaing dengan kedelai dari luar negeri. Penyebab produksi kedelai menurun diantaranya cekaman kekeringan, penyakit, gangguan hama, dan kekurangan unsur hara (Suherman \& Akib 2012).

Upaya untuk meningkatkan pertumbuhan dan produksi tanaman kedelai salah satunya adalah pemupukan dengan menggunakan pupuk anorganik NK. Pemupukan tanaman bertujuan untuk menyediakan hara atau memberi energi untuk tanaman agar tanaman dapat tumbuh menjadi lebih subur (Dewi \& Nugroho 2011). Menurut Taufiq (2014), unsur N dalam jumlah cukup dapat meningkatkan pertumbuhan vegetatif tanaman, berperan dalam penyusun klorofil dan pembentukan protein. Unsur $\mathrm{K}$ berpengaruh untuk perkembangan klorofil yaitu mengatur penutupan dan pembukaan stomata.

Upaya lain yang dapat dilakukan adalah memberikan penambahan FMA sebagai pupuk hayati pendamping pupuk anorganik untuk meningkatkan pertumbuhan dan produktivitas tanaman kedelai. FMA merupakan jamur tanah yang mampu bersimbiosis dengan akar tanaman sehingga dapat membantu proses penyerapan unsur hara terutama unsur $\mathrm{P}$ dan air, dapat memperluas daerah penyerapan akar, meningkatkan ketahanan tanaman dari kekeringan, dan melindungi dari serangan patogen. Unsur P menurut Puteri et al. (2014), berperan selama perkecambahan hingga waktu panen, kekurangan unsur $\mathrm{P}$ dapat menghambat pertumbuhan tanaman kedelai. Hal ini didukung oleh Samosir et al. (2015), bahwa unsur P berfungsi dalam pertumbuhan tanaman kedelai dan mempercepat matangnya polong. Meski telah banyak penelitian mengenai peranan FMA, namun penelitian tentang kombinasi FMA dengan pupuk anorganik dalam meningkatkan pertumbuhan dan produksi tanaman kedelai lokal Bali belum banyak dilakukan. Maka dari itu, perlu dilakukan penelitian yang bertujuan untuk mengetahui peranan FMA Glomus sp. dan pupuk NK terhadap produktivitas tanaman kedelai (Glycine max (L.) Merril) var. Lokal Bali.

\section{Metoda Penelitian}

Penelitian ini dilaksanakan pada bulan Desember 2018 sampai Mei 2019 di Laboratorium Taksonomi Tumbuhan/Mikologi dan Shading house Program Studi Biologi, Fakultas Matematika dan Ilmu Pengetahuan Alam, Universitas Udayana. Bahan yang digunakan dalam penelitian ini adalah benih kedelai (berasal dari petani lokal Bali), polybag $20 \times 40 \mathrm{~cm}$, pupuk 
NK, dan campuran tanah pasir 1:1 yang sudah disterilisasi. Tiap polybag berisi $10 \mathrm{~kg}$ tanah. Jenis FMA yang digunakan adalah Glomus sp. dari Koleksi Laboratorium Mikologi, Universitas Udayana.

Penelitian ini menggunakan Rancangan Acak Kelompok dengan 5 perlakuan yaitu kontrol (tanah steril)/ tanpa inokulasi dan pupuk NK (A), tanah steril dan 50 spora Glomus sp. (B), tanah steril, 50 spora Glomus sp. dan pupuk NK $5 \mathrm{~g}$ (C), tanah steril, 50 spora Glomus sp. dan pupuk NK 10 g (D), tanah steril, 50 spora Glomus sp. dan pupuk NK 15 g (E). Penelitian ini menggunakan lima ulangan dengan setiap ulangan terdiri dari tiga unit tanaman sehingga keseluruhan tanaman berjumlah 75 tanaman $(5 \times 5 \times 3)$. Prosedur penelitian yang dilakukan adalah penyaringan dan penghitungan spora Glomus sp., persiapan media tanam, penanaman benih kedelai, inokulasi FMA Glomus sp., dan pemberian pupuk anorganik NK. Variabel yang diamati adalah tinggi tanaman, berat kering tajuk, berat kering akar, jumlah polong isi dan polong hampa, berat basah dan berat kering polong, dan persentase kolonisasi FMA. Data yang diperoleh dianalisis menggunakan analysis of varians (ANOVA) dan bila terdapat perbedaan pengaruh yang nyata dilanjutkan dengan uji jarak berganda dari Duncan's 5\%.

Prosedur pewarnaan kolonisasi dilakukan dengan beberapa tahapan yaitu clearing, staining, dan destaining. Kolonisasi FMA pada akar tanaman dihitung menggunakan metode slide (Giovannetti \& Mosse 1980). Potongan akar yang telah diwarnai disusun di atas kaca preparat sebanyak 10 - 15 potongan untuk diamati dengan mikroskop. Bagian yang menunjukkan tanda-tanda kolonisasi ditandai adanya hifa, vesikel dan atau arbuskula diberi tanda (+). Perhitungan presentase kolonisasi FMA pada akar tanaman menggunakan rumus sebagai berikut :

$$
\% \text { Kolonisasi FMA pada akar }=\frac{\text { Jumlah akar yang terkolonisasi }}{\text { Jumlah akar yang diamati }} \times 100 \%
$$

Adapun kriteria tinggi dan rendahnya persentase kolonisasi akar dihitung menurut Setiadi et al. (1992) seperti pada Tabel 1. berikut :

Tabel 1. Kriteria Kolonisasi FMA Pada Akar

\begin{tabular}{cc}
\hline Kelas & Kriteria \\
\hline 1 & $0-5 \%$ (sangat rendah) \\
2 & $6-26 \%$ (rendah) \\
3 & $26-50 \%$ (sedang) \\
4 & $51-75 \%$ (tinggi) \\
5 & $76-100 \%$ (sangat tinggi) \\
\hline
\end{tabular}

\section{Hasil}

Hasil penelitian menunjukkan bahwa pemberian 50 butir spora Glomus sp. dan pupuk NK 5 g pada perlakuan $C$ berperan meningkatkan produktivitas tanaman kedelai terlihat pada jumlah polong isi sebanyak 51 polong per tanaman yang berbeda nyata secara statistik dan memiliki berat kering sebesar 9,10 g, tetapi perlakuan ini tidak memberikan pengaruh yang berbeda nyata terhadap pertumbuhan tanaman kedelai.

\section{Tinggi tanaman}

Tinggi tanaman kedelai pada perlakuan E memiliki nilai tertinggi sebesar $87,13 \mathrm{~cm}$ dan terendah pada perlakuan A (tanah steril/kontrol) sebesar $81,09 \mathrm{~cm}$. Perbedaan tinggi tanaman dapat dilihat pada Gambar 1. 


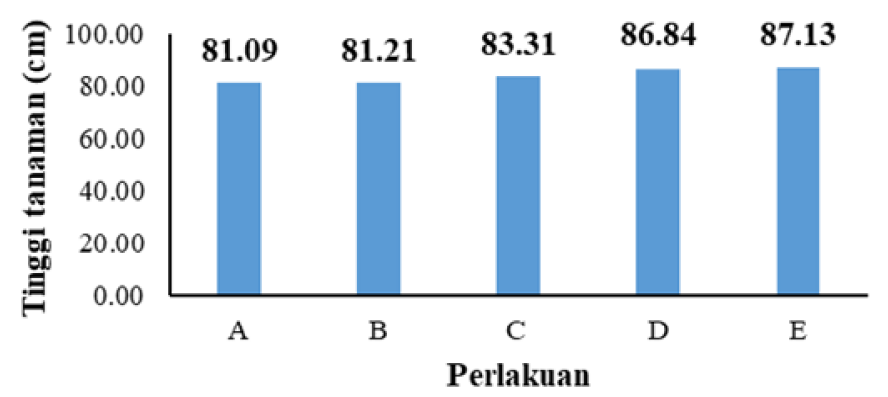

Gambar 1. Rata-rata tinggi tanaman. A. Tanah steril (kontrol). B. Tanah steril, 50 spora Glomus sp. C. Tanah steril, 50 spora Glomus sp. dan pupuk NK 5 g. D. Tanah steril, 50 spora Glomus sp. dan pupuk NK $10 \mathrm{~g}$. E. Tanah steril, 50 spora Glomus sp. dan pupuk NK $15 \mathrm{~g}$.

\section{Berat kering tajuk}

Pengukuran berat kering tajuk (tanpa polong dan akar) menunjukkan berat kering tajuk tertinggi pada perlakuan D sebesar $12,38 \mathrm{~g}$ dan terendah pada perlakuan B sebesar 7,96 $\mathrm{g}$ (Gambar 2.)

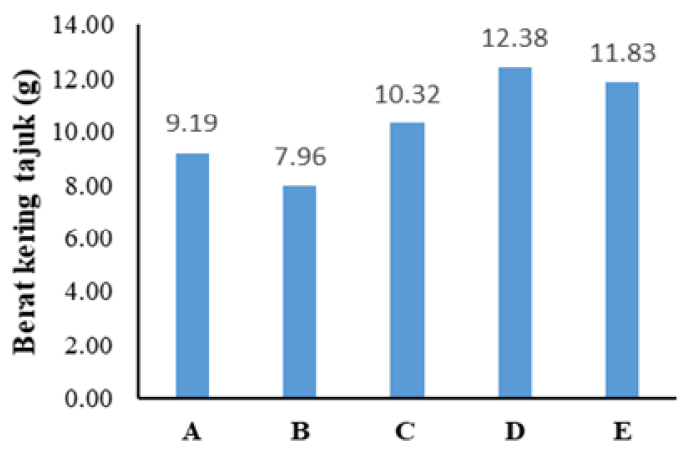

Gambar 2. Rata-rata berat kering tajuk. A. Tanah steril (kontrol). B. Tanah steril, 50 spora Glomus sp. C. Tanah steril, 50 spora Glomus sp. dan pupuk NK 5 g. D. Tanah steril, 50 spora Glomus sp. dan pupuk NK 10 g. E. Tanah steril, 50 spora Glomus sp. dan pupuk NK 15 g.

\section{Berat kering akar}

Pada Gambar 3. menunjukkan berat kering akar tertinggi terdapat pada perlakuan B sebesar 2,99 $\mathrm{g}$ dan terendah pada perlakuan E sebesar 1,36 $\mathrm{g}$.

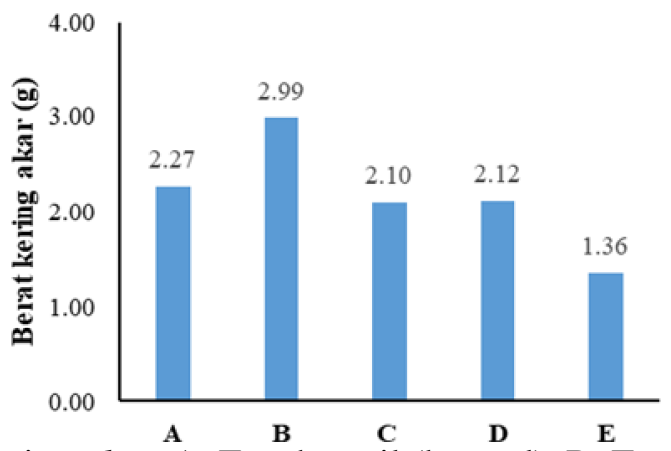

Gambar 3. Rata-rata berat kering akar. A. Tanah steril (kontrol). B. Tanah steril, 50 spora Glomus sp. C. Tanah steril, 50 spora Glomus sp. dan pupuk NK 5 g. D. Tanah steril, 50 spora Glomus sp. dan pupuk NK $10 \mathrm{~g}$. E. Tanah steril, 50 spora Glomus sp. dan pupuk NK $15 \mathrm{~g}$.

\section{Jumlah polong isi}

Perlakuan $\mathrm{C}$ menghasilkan jumlah polong isi tertinggi sebanyak 51 polong per tanaman dan terendah pada perlakuan E sebanyak 26 polong per tanaman (Gambar 4.) 


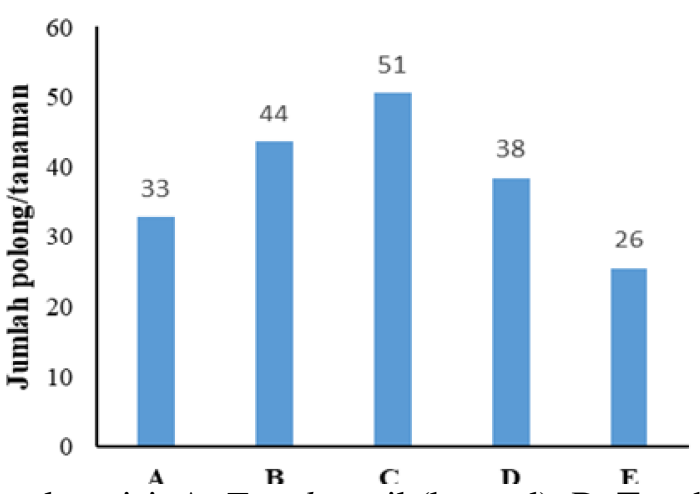

Gambar 4. Rata-rata jumlah polong isi. A. Tanah steril (kontrol). B. Tanah steril, 50 spora Glomus sp. C. Tanah steril, 50 spora Glomus sp. dan pupuk NK 5 g. D. Tanah steril, 50 spora Glomus sp. dan pupuk NK 10 g. E. Tanah steril, 50 spora Glomus sp. dan pupuk NK $15 \mathrm{~g}$.

\section{Jumlah polong hampa}

Jumlah polong hampa tertinggi pada perlakuan D sebanyak 33 polong per tanaman dan terendah pada perlakuan B sebanyak 15 polong per tanaman (Gambar 5.)

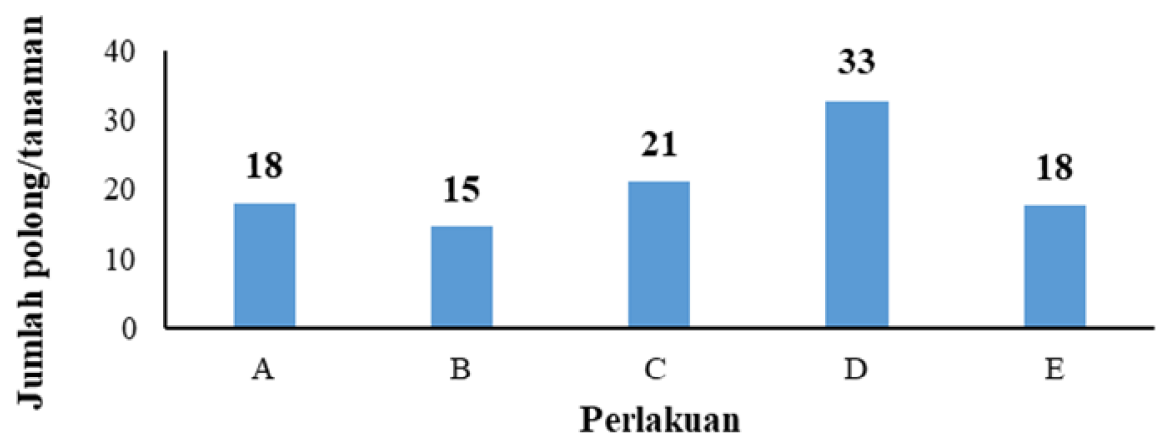

Gambar 5. Rata-rata jumlah polong hampa. A. Tanah steril (kontrol). B. Tanah steril, 50 spora Glomus sp. C. Tanah steril, 50 spora Glomus sp. dan pupuk NK 5 g. D. Tanah steril, 50 spora Glomus sp. dan pupuk NK 10 g. E. Tanah steril, 50 spora Glomus sp. dan pupuk NK $15 \mathrm{~g}$.

\section{Berat basah polong}

Berat basah polong tertinggi terdapat pada perlakuan D sebesar $66,75 \mathrm{~g}$ per tanaman dan terendah pada perlakuan E sebesar 20,83 per tanaman (Gambar 6).

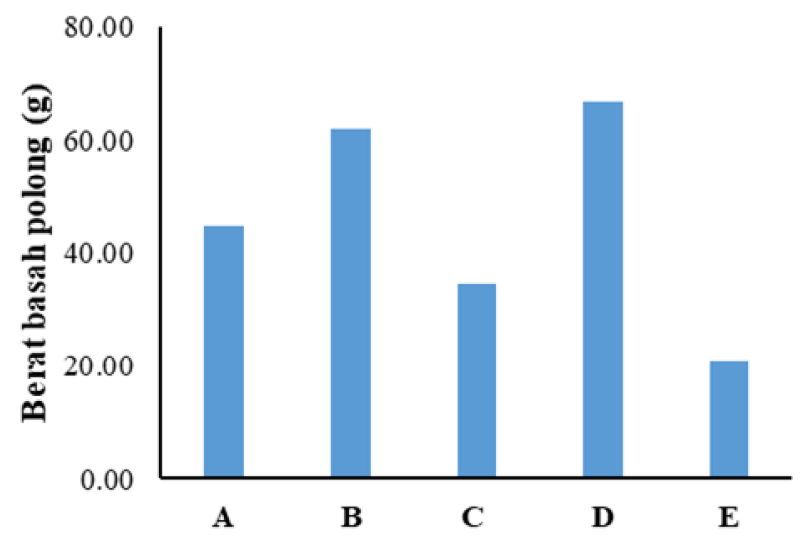

Gambar 6. Rata-rata berat basah polong. A. Tanah steril (kontrol). B. Tanah steril, 50 spora Glomus sp. C. Tanah steril, 50 spora Glomus sp. dan pupuk NK 5 g. D. Tanah steril, 50 spora Glomus sp. dan pupuk NK 10 g. E. Tanah steril, 50 spora Glomus sp. dan pupuk NK 15 g. 


\section{Berat kering polong}

Berat kering polong tertinggi terdapat pada perlakuan B sebesar 9,13 g per tanaman dan terendah pada perlakuan E sebesar 6,41 g per tanaman (Gambar 7.).

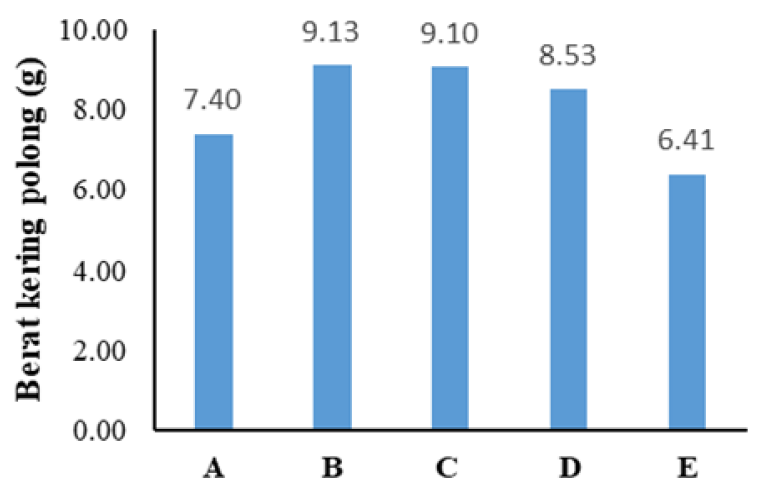

Gambar 7. Rata-rata berat kering polong. A. Tanah steril (kontrol). B. Tanah steril, 50 spora Glomus sp. C. Tanah steril, 50 spora Glomus sp. dan pupuk NK 5 g. D. Tanah steril, 50 spora Glomus sp. dan pupuk NK 10 g. E. Tanah steril, 50 spora Glomus sp. dan pupuk NK 15 g.

\section{Persentase kolonisasi FMA Glomus sp.}

Hasil pengamatan pada akar kedelai menunjukkan kolonisasi endomikoriza ditemukan pada perlakuan B, C, D dan E. Persentase kolonisasi FMA tertinggi terdapat pada perlakuan B yaitu 86,67\%, sedangkan pada perlakuan A tidak ditemukan kolonisasi FMA pada akar tanaman (Gambar 8.)

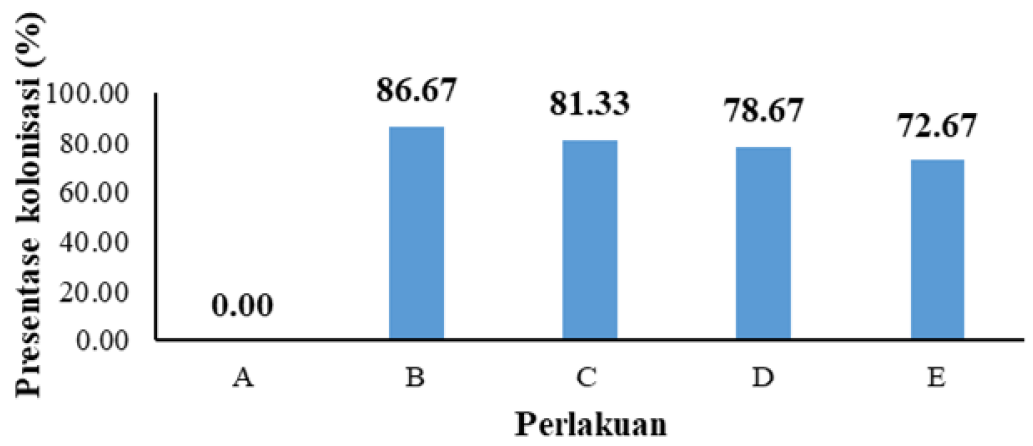

Gambar 8. Rata-rata persentase kolonisasi FMA Glomus sp. A. Tanah steril (kontrol). B. Tanah steril, 50 spora Glomus sp. C. Tanah steril, 50 spora Glomus sp. dan pupuk NK 5 g. D. Tanah steril, 50 spora Glomus sp. dan pupuk NK 10 g. E. Tanah steril, 50 spora Glomus sp. dan pupuk NK $15 \mathrm{~g}$.

\section{Pembahasan \\ Tinggi tanaman}

Pertumbuhan tanaman kedelai antara perlakuan kontrol negatif (A) dengan tanaman yang diinokulasi FMA tidak berbeda jauh. Hal ini diduga karena pada akar tanaman kontrol (A) terdapat Rhizobium yang cukup banyak. Keberadaan Rhizobium diduga disebabkan metode sterilisasi kukus kurang efektif untuk bakteri. Hal ini didukung oleh hasil penelitian Cahyani (2009), bahwa sterilisasi kukus dapat mematikan FMA sedangkan Rhizobium masih terdapat dalam tanah. Tingginya pertumbuhan tanaman pada perlakuan $\mathrm{E}$ diduga karena mendapat inokulasi FMA dan pupuk NK. Hal ini didukung oleh hasil penelitian Trisilawati et al. (2012), bahwa pemberian FMA dan pupuk anorganik dapat meningkatkan tinggi tanaman jambu mete dibandingkan tanpa pemberian FMA dan pupuk anorganik karena mampu menyediakan unsur hara bagi tanaman 


\section{Berat kering tajuk}

Berat kering tajuk tertinggi terdapat pada perlakuan B, diduga tanaman hanya dibantu mikoriza untuk memperoleh unsur hara sehingga berat kering tajuk rendah, sedangkan pada perlakuan D tanaman mendapat tambahan hara dari pupuk NK. Menurut Prasasti et al. (2013), berat kering tanaman menunjukkan pertumbuhan tanaman dan banyaknya unsur hara yang diserap oleh tanaman. Semakin tinggi berat kering tanaman menunjukkan pertumbuhan tanaman semakin baik dan unsur hara serta air yang diserap oleh tanaman semakin banyak. Ketersediaan kalium dari pupuk anorganik diduga dapat mempengaruhi pertumbuhan tanaman. Unsur $\mathrm{K}$ berperan memacu translokasi karbohidrat dari daun ke organ tanaman lain dan dapat menjaga batang tetap tegak sehingga distribusi air dapat berjalan dengan baik (Subandi 2013).

\section{Berat kering akar}

Pada perlakuan B didapatkan berat kering akar tertinggi, diduga karena tanaman pada perlakuan B hanya memperoleh unsur hara yang berasal dari FMA. Tersedianya FMA pada media tanam membantu menguatkan sistem perakaran dalam menyerap unsur hara, terutama unsur P dan air. Menurut Prasasti et al. (2013), pemberian 250 spora FMA berpengaruh terhadap pemanjangan sel-sel akar sehingga mempengaruhi berat kering akar tanaman kacang tanah. Hal ini didukung oleh hasil penelitian Malik et al. (2017), bahwa pemberian FMA pada tanaman kedelai tanpa diberikan pupuk memiliki berat kering akar lebih berat. Hal ini menunjukkan FMA dapat membantu penyerapan unsur $\mathrm{P}$ yang menyebabkan terjadinya pemanjangan akar yang akan memperluas daerah penyerapan.

Pada perlakuan E didapatkan berat kering akar terendah diduga karena adanya tambahan unsur hara dari pupuk NK. Adanya tambahan unsur hara dapat membantu pertumbuhan tanaman berjalan dengan baik, sehingga pertumbuhan tanaman tidak hanya berfokus pada akar (Fahmi et al. 2014). Hal lainnya yang diduga menyebabkan berat kering akar menjadi rendah adalah penggunaan pupuk yang berlebihan, dosis pupuk anorganik $15 \mathrm{~g}$ merupakan dosis tertinggi dari semua perlakuan.

\section{Jumlah polong isi}

Jumlah polong isi (polong yang di dalamnya terdapat biji) tertinggi pada perlakuan $\mathrm{C}$ (50 butir spora dan pupuk anorganik $5 \mathrm{~g}$ ) sebesar 51 polong per tanaman dan terendah pada perlakuan E sebesar 26 polong per tanaman (Gambar 4.). Adanya tambahan unsur hara pada media tanam dari pupuk NK dan FMA dapat membantu pertumbuhan dan perkembangan tanaman. Ayunita et al. (2014) menyatakan, unsur P yang didapat dari FMA berperan dalam aktivitas fotosintesis, sehingga meningkatnya hasil fotosintesis menyebabkan proses pematangan polong cepat dan unsur $\mathrm{K}$ dari pupuk anorganik berperan memacu pengangkutan karbohidrat dari daun ke organ tanaman lainnya, sehingga hasil fotosintesis dapat digunakan dengan baik, diantaranya pembentukan polong (Subandi 2013, Wahyudin et al. 2017). Jumlah polong isi terendah pada perlakuan E yang dapat terjadi karena penggunaan pupuk yang berlebihan, sehingga pertumbuhan kedelai terganggu. Hal ini didukung oleh hasil penelitian Marlina et al. (2015), pemberian dosis pupuk yang berlebihan pada tanaman kedelai menghasilkan jumlah polong per tanaman terendah yang disebabkan terhambatnya translokasi karbohidrat sehingga mempengaruhi jumlah polong isi.

\section{Jumlah polong hampa}

Jumlah polong hampa (polong yang didalamnya tidak terdapat biji) tertinggi terdapat pada perlakuan D sebesar 33 polong per tanaman dan terendah pada perlakuan B sebesar 15 polong per tanaman (Gambar 5). Adanya hama pada perlakuan D dapat menyebabkan jumlah polong hampa meningkat, sehingga jumlah polong hampa tinggi. Tingginya jumlah polong 
hampa dapat disebabkan adanya hama selama penelitian, misalnya Aphis glycines dan kepik (Riptortus linearis). Hal ini serupa dengan penelitian Zakka et al. (2016), pada tanaman yang diberi pupuk anorganik akan menyebabkan tanaman terlihat lebih subur, sehingga tanaman menjadi terlihat lebih menarik bagi hama. Menurut Sarjan \& Sab'i (2014), serangga sangat tertarik dengan kelompok tanaman kacang-kacangan. Hal lainnya yang dapat mempengaruhi hasil tanaman kedelai adalah kurangnya jumlah spora FMA yang diberikan pada tanaman. Hal ini didukung oleh hasil penelitian Abror \& Mauludin (2015) yang menyatakan pemberian FMA dapat meningkatkan produksi cabai rawit dengan menggunakan $1 \mathrm{~kg}$ tanah dengan kandungan spora sekitar 20 spora per gram tanah.

\section{Berat basah polong}

Pada perlakuan D didapatkan berat basah polong per tanaman tertinggi sebesar $66,74 \mathrm{~g}$ (Gambar 6). Pemberian FMA dan pupuk NK pada tanaman kedelai dapat meningkatkan berat basah polong. Hal ini didukung oleh hasil penelitian Rosliani \& Sumarni (2009), pemberian inokulasi FMA pada tanaman cabai didampingi pupuk memiliki berat buah yang lebih berat dibandingkan tanpa didampingi pupuk. Pemberian FMA dapat membantu penyerapan unsur hara dan air, sedangkan pemberian pupuk menyebabkan unsur hara menjadi tersedia pada media tanam.

\section{Berat kering polong}

Berat kering polong per tanaman tertinggi dapat dilihat pada perlakuan B sebesar $9,13 \mathrm{~g}$ (Gambar 7). Inokulasi FMA pada tanaman kedelai dapat meningkatkan berat kering polong per tanaman. Hal ini didukung oleh hasil penelitian Sampurno et al. (2010), pemberian FMA pada tanaman kacang tanah menghasilkan berat kering polong yang lebih berat dibandingkan tanpa pemberian FMA. FMA dapat meningkatkan penyerapan hara terutama hara $\mathrm{P}$, sehingga dapat menghasilkan berat kering polong yang lebih berat.

\section{Persentase kolonisasi FMA}

Hasil pengamatan pada akar kedelai menunjukkan kolonisasi FMA ditemukan pada perlakuan B, C, D dan E sedangkan pada perlakuan A tidak ditemukan kolonisasi FMA pada akar tanaman (Gambar 8). Hal ini didukung oleh hasil penelitian Malik et al. (2017), tanaman yang mendapat inokulasi FMA memiliki persentase kolonisasi lebih tinggi dibandingkan tanpa inokulasi FMA. Penggunaan pupuk juga dapat mempengaruhi persentase kolonisasi, dapat dilihat semakin meningkat penggunaan pupuk menyebabkan terjadinya penurunan persentase kolonisasi FMA (Gambar 8). Musfal (2008) menyatakan, bahwa persentase kolonisasi FMA meningkat pada akar tanaman yang tidak diberikan pupuk. Menurut Sumiati \& Gunawan (2006), bila tingkat kesuburuan tanah tinggi, menyebabkan FMA kurang responsif menginfeksi akar tanaman inang karena jamur tersebut sudah mendapatkan nutrisi dari tanah. Banyaknya pupuk yang diberikan pada tanaman akan berpengaruh terhadap tinggi rendahnya persentase kolonisasi FMA pada akar (Muzar 2006). Pada akar tanaman perlakuan A tidak ditemukan kolonisasi FMA (0\%). Tidak ditemukannya kolonisasi dapat terjadi karena FMA tidak diberikan pada perlakuan tersebut dan tanah yang steril tidak memungkinkan spora FMA berkecambah dan menginfeksi akar tanaman perlakuan A. Hal ini didukung oleh hasil penelitian Sagala et al. (2013), media tanam yang telah disterilisasi dan tidak mendapat inokulasi FMA menyebabkan akar tanaman tidak terkolonisasi, kemungkinan FMA yang secara alamiah ada pada media tanam dalam keadaan tidak aktif lagi.

\section{Ucapan Terima Kasih}

Penulis pertama (NAT) dan penulis ketiga $(\mathrm{JH})$ mengucapkan terima kasih atas dana yang diberikan oleh penulis kedua (MWP) sebagai Ketua Penelitian Dasar Unggulan 
Perguruan Tinggi (PDUPT) tahun anggaran 2018 Kemenristek DIKTI dengan nomor kontrak 171.65/UN14.4.A/LT/2018.

\section{Pustaka}

Abror M, Mauludin M. 2015- Pengaruh Pemberian Mikoriza Vesikular Arbuskula terhadap Efisiensi Penyerapan Fosfat pada Pertumbuhan dan Produksi Cabai Rawit (Capsicum frutescens L.). Nabatia Journal of Agricultural Science 12(1), 51-62.

Aimon H, Satrianto A. 2014- Prospek Konsumsi dan Impor Kedelai di Indonesia Tahun 2015 - 2020. Jurnal Kajian Ekonomi 3(5), 1-13.

Ayunita I, Mansyoer A, Sampoerno. 2014- Uji Beberapa Dosis Pupuk Vermikompos pada Tanaman Kacang Hijau (Vigna radiata L.). Jom Faperta 1(2), 1-11.

Cahyani VR. 2009 - Pengaruh Beberapa Metode Sterilisasi Tanah terhadap Status Hara, Populasi Mikrobiota, Potensi Infeksi Mikorisa dan Petumbuhan Tanaman. Jurnal Ilmiah Ilmu Tanah dan Agroklimatologi 6(1), 43-52.

Dewi TQ, Nugroho S. 2011- Tips Membuahkan Tanaman dalam Pot. Penebar Swadaya, Bogor.

Fahmi N, Syamsuddin, Marliah A. 2014- Pengaruh Pupuk Organik dan Anorganik terhadap Pertumbuhan dan Hasil Kedelai (Glycine max (L.) Merril). Jurnal Floratek 9(1), 53-62.

Giovannetti M, Mosse B. 1980- An Evaluation Technique for Measuring VesicularArbuscular Mycorrhizal Infection in Roots. Journal New Phytologist. 84(1), 489-500.

Kementerian Pertanian. 2016- Outlook Komoditas Pertanian Tanaman Pangan Kedelai. http://epublikasi.setjen.pertanian.go.id/epublikasi/outlook/2016/Tanpang/OUTLOOK\% 20KEDELAI\%202016/files/assets/common/downloads/OUTLOOK\%20KEDELAI\%20 2016.pdf. - 2018.

Malik M., Hidayat KF, Yusnaini S, Rini MV. 2017- Pengaruh Aplikasi Fungi Mikoriza Arbuskula dan Pupuk Kandang dengan Berbagai Dosis Terhadap Pertumbuhan dan Produksi Kedelai (Glycine max (L.) Merrill) Pada Ultisol. Jurnal Agrotek Tropika 5(2), 63-67.

Marlina E, Anom E, Yoseva S. 2015- Pengaruh Pemberian Pupuk NPK Organik Terhadap Pertumbuhan dan Produksi Kedelai (Glycine Max (L.) Merril). Jom Faperta 2(1), 1-13.

Musfal. 2008- Efektivitas Cendawan Mikoriza Arbuskula (CMA) terhadap Pemberian Pupuk Spesifik Lokasi Tanaman Jagung pada Tanah Inceptisol. (Tesis). Universitas Sumatera Utara.

Muzar A. 2006- Respon Tanaman Jagung (Zea mays L.) Kultivar Arjuna dengan Populasi Tanaman Bervariasi terhadap Mikoriza Vesikular Arbuskula (MVA) dan Kapur Pertanian Superfosfat (KSP) pada Ultisol. Akta Agrosia 9(2), 75-85.

Prasasti O H, Purwani KI, Nurhatika S. 2013- Pengaruh Mikoriza Glomus fasciculatum terhadap Pertumbuhan Vegetatif Tanaman Kacang Tanah yang Terinfeksi Patogen Sclerotium rolfsii. Jurnal Sains dan Seni Pomits 2(2), 74-78.

Puteri EA, Nurmiaty Y, Agustiansyah. 2014- Pengaruh Aplikasi Fosfor dan Silika terhadap Pertumbuhan dan Hasil Tanaman Kedelai (Glycine max (L.) Merrill.). Jurnal Agrotek Tropika 2(2), 241-245.

Rosliani R, Sumarni N. 2009- Pemanfaatan Mikoriza dan Aplikasi Pupuk Anorganik pada Tumpangsari Cabai dan Kubis di Dataran Tinggi. Jurnal Hortikultura 19(3), 313-323.

Sagala Y, Hanafiah AS, Razali. 2013- Peranan Mikoriza terhadap Pertumbuhan, Serapan P dan Cd Tanaman Sawi (Brassica juncea L.) serta Kadar P dan Cd Andisol yang Diberi Fosfat Alam. Jurnal Agroekoteknologi 2(1), 487-500.

Samosir RK, Lahay RR, Damanik RI. 2015- Respon Pertumbuhan dan Produksi Kedelai (Glycine max (L.) Merrill) terhadap Pemberian Kompos Sampah Kota dan Pupuk P. Jurnal Agroekoteknologi 4(1), 1838-1848. 
Sampurno, Elsie, Riana O. 2010- Pemanfaatan Cendawan Mikoriza Arbuskular (CMA) pada Beberapa Jenis Tanah terhadap Pertumbuhan Kacang Tanah (Arachis hypogaea L.). SAGU. 9(1), 28-37.

Sarjan, M, I. Sab'i. 2014- Karakteristik Polong Kedelai Varietas Unggul yang Terserang Hama Pengisap Polong (Riptortus linearis) pada Kondisi Cekaman Kekeringan. Jurnal Lahan Suboptimal 3(2), 168-180.

Setiadi Y, Mansur, Achmad. 1992- Mikrobiologi Tanah Hutan. Pusat Antar Universitas Bioteknologi Tanaman Pangan. IPB, Bogor.

Subandi. 2013- Peran dan Pengelolaan Hara Kalium untuk Produksi Pangan di Indonesia. Pengembangan Inovasi Pertanian 6(1), 1-10.

Suherman IR, Akib A. 2012- Aplikasi Endomikoriza Vesikular Arbuskular terhadap Pertumbuhan dan Produksi Tanaman Kedelai (Glycine max L. Merrill). Jurnal Galung Tropika 1(1), 1-6.

Sumiati E, Gunawan OS. 2006- Aplikasi Pupuk Hayati Mikoriza untuk Meningkatkan Efisiensi Serapan Unsur Hara NPK serta Pengaruhnya terhadap Hasil dan Kualitas Umbi Bawang Merah. Jurnal Hortikultura 17(1), 34-42.

Taufiq A. 2014- Identifikasi Masalah Keharaan Tanaman Kedelai. Balai Penelitian Tanaman Aneka Kacang dan Umbi, Malang.

Trisilawati O, Towaha J, Daras U. 2012- Pengaruh Mikoriza dan Pupuk NPK terhadap Pertumbuhan dan Poduksi Jamu Mete Muda. Buletin RISTRI 3(1), 91-98.

Wahyudin A., Wicaksono FY, Irwan AW, Ruminta, Fitriani R. 2017- Respon Tanaman Kedelai (Glycine max) Varietas Wilis Akibat Pemberian Berbagai Dosis Pupuk N, P, K, dan Pupuk Guano pada Tanah Inceptisol Jatinangor. Jurnal Kultivasi 16(2), 333-339.

Zakka U, Atijegbe SR, Lale NES, Kalu ER. 2016- Effects oof Poultry Manure and NPK Fertilizer on Infestation of Musk Pumpkin (Cucurbita maxima) by Insect Pests. International Journal of Plant \& Soil Science 11(3), 1-8. 